\title{
Vaenunimedest eesti internetis
}

Liisi Laineste

Teesid: Nimetamine on tegevus, mille kaudu otse öeldes, kuid ka eufemisme ja düsfemisme kasutades, tõmmatakse piire ja luuakse kategooriaid. Vaenunimed võivad omandada negatiivse tähenduse alles kontekstis, teised aga kannavad tabu-ja vandesõnadena või negatiivse võrdlusena juba niigi halvustavat tähendust. Nimetamine on seotud ka võimuküsimusega: nime andmine on lisaks taustast eristamisele ka hinnangu andmine, võimupositsiooni võtmine.

Vaenunimed kui düsfemistlikud nimetused esinevad tänapäeval sageli internetikommentaarides, mille tajutav anonüümsus lubab ja isegi soodustab nende negatiivsete väljendite kasutamist. Käesolev uurimus kirjeldab delfi.ee uudiskommentaarides esinevaid vaenunimesid aastatel 2000-2007, nende kitsamat (konkreetne kommentaar) ja laiemat (sotsiaalne, poliitiline jm) konteksti ning arutleb nende funktsiooni üle ühiskonnas.

Märksõnad: Agressiivsus, düsfemismid, etniline huumor, etniline vaen, internetifolkloor, vaenunimed.

\section{Sissejuhatus}

Vaenunimed on ilmseimad eelarvamuslikkuse, etnotsentrismi, aga ka otsese ksenofoobia e võõravaenu avaldusi. Nende baasiks on teise erinevuste rõhutatult naeruvääristav, ühekülgne, äärmustesse viidud kujutamine (nt konnasöö$j a$ = prantslane). Kuid nad pole ainult seda - vaenunimed on ka interetniliste suhete ajaloo suurepärane peegel. Etnilise vaenu sõnavara on reaktsiooniks ühiskonna etnilisele mitmekesistumisele, seda mõjutavad objektiivsed tegurid nagu rahvastiku arv ja tihedus, migratsioonimustrid jm, olles suurepäraseks näiteks sellest, kuidas sotsiaalne reaalsus kujundab kultuuri, täpsemalt sõnavara. Kohanimede uurija Robert Ramsay on öelnud, et kui meil oleks täielik ajalooline arhiiv kõikidest sõnadest mis kunagi on loodud, muudetud ja unustatud, saaks sellest mistahes ajaloolisest kirjeldusest üsna objektiivne ülevaade rahvuse ja tema suhete, hoiakute ja kommete kohta (tsiteerinud 
Allen 1983: 7). Vaenunimede objektiks võib olla mistahes teine: etniline, aga ka majanduslik, poliitiline, sotsiaalne võõras (sageli on vaenunimede objektiks esiplaanil olevad poliitikud, nt savipäts = Edgar Savisaar jne). Siinkohal keskendun eelkõige etnilisele, vähemal määral ka religioossele teisele.

Vaenunimed tekitavad eristust oma ja võõra vahel, toimides kontsentraadina enamasti keerulisemalt sõnastatavatest etnilistest (ja muude gruppidega seotud) stereotüüpidest, nad on emotsionaalsed, kuid samaaegselt ratsionaalselt põhjendatavad laiema ühiskondliku kontekstiga. Traditsiooniliselt kuuluvad vaenunimed slängiväljendite alla ning asuvad seega folkloristika käsitlusalas, siinne ülevaade paigutub siiski pigem sotsioloogilise ja folkloristliku lähenemise ristumispunkti. Käesolev artikkel annab ülevaate vaenunimedest eesti internetis, analüüsides Delfi uudisteportaali kommentaare aastatel 20002007. Internet pakub piiramatuid võimalusi näiliselt anonüümseks ja karistamatuks vaenamiseks (inglise k flaming või hate speech), mida leidub palju ka Delfi materjalis. Käsitletakse põhilisi objekte ja nimetusi ning nende osas nähtuvate trendide sotsiaalseid tagamaid. Samuti arutletakse vaenunimede funktsiooni üle ühiskonnas, viidates sellele, et nende kasutamine on erinevatel perioodidel kas intensiivsem või tagasihoidlikum. Jälgitakse ka seda, kas vaenunimede objektid langevad kokku anekdooditegelaste valikuga, et heita enam valgust agressiivsuse ja huumori vastasmõjule. Vaenunimed kui rahvustunde tugevuse indikaator vajaks lisaks siinsele käsitlusele ka sotsiaalpsühholoogilisi (avalikkuse, meedia, poliitikute jt vaenunime objektide suhtumine vaenukõnesse, vaenukõne mõju hoiakutele ja käitumisele) ja kultuuridevahelisi uuringuid, aga ka ülevaadet eestikeelsete etniliste vaenunimede etümoloogiast ning nende kujunemise ajaloost; siin keskendutakse põhiliselt (nüüdisaegse) fenomeni üldisele kirjeldamisele ja meediumi mõju analüüsile.

\section{Nimetamine}

Nimetamine on üldinimlik tegevus, mis katab kogu tunnetuse areaali - nimetada tähendab tunda. Jagades maailma eraldiseisvateks ühikuteks, mida tähistavad kokkuleppelised sõnad, organiseerivad nimetused keskkonda kergemini tajutavaks. Nimetamine on objektidest mõtlemise ja kõnelemise elementaarne eeletapp. Kedagi tähistades võtab nimetaja positsiooni, milles ta identifitseerib teatud grupiga ja vastandub teistele. Kategoriseeritus toob aga implitsiitselt kaasa hinnangulised vastandused (nt oma - võõras on kirjeldatav ka kategooriates hea - halb). Nimetamine on esmane samm omailma loomisel, aga ka laiemas mõttes nt rahvuse eneseidentifitseerimisel, oma eristamisel teisest, võõrast maailmast. Pärisnimedes aksioloogiline mõõde enamasti puu- 
dub. Pärisnime defineeritakse sageli selle tähendusetuse järgi (Vaik 2006). Kuid hüüdnime funktsioon on kanda endas kõike seda, mida pärisnimi ei võimalda, luua potentsiaalseid lisatähendusi, olgu siis negatiivseid või positiivseid. Sellega läheneb see oma tähenduspotentsiaali mõttes sümbolile. Nimedel, hüüd- ja vaenunimedel on palju ühisjooni. Käesolevas uurimuses on nimetamist ja vaenunimesid käsitletud ühe nähtuse eri avaldusvormidena. Vaenunime definitsioon põhineb kontekstil, milles nimetus esineb, haarates sellega nii objektiivselt neutraalseid (venelane) kui ka selgelt negatiivseid slängiväljendeid (pepuvend $=$ homoseksuaal). Sõnade formaalne eristamine neutraalseteks ja negatiivseteks pole alati võimalik. Siin käsitletava materjali, interneti uudisekommentaaride puhul on iga etniline nimetus võetav solvanguna, kui see on paigutatud vastavasse konteksti, nt osana tulisest vaidlusest päevakajalisel teemal. Reaktsioon igasugusele vaenamisele, sh vaenunimedele, enamasti puudub. Tsenseerimine, korralekutsumine või avalik taunimine pole (veel) kombeks, kuigi leimiseadus astus juba aastal 2005 selles osas esimese sammu (leim on eestikeelne vaste inglisekeelsele sõnale flame, mille üheks tähenduseks on internetis solvangute ja mõnitavate sõnumite levitamine; vt ka http://www.leim.ee/full.php). Internetti iseloomustab sellele meediumile omane vastutustundetu agressiivsus kombineeritud iroonia ja huumoriga, mis vastastikku teineteist nii rõhutavad kui ka neutraliseerivad: rõhutavad selle kaudu, et "rünnak" muutub kujundlikumaks ja meeldejäävamaks, neutraliseerivad aga argumendiga agressiivsuse näilisusest, mängulisusest. Tuleohtlikult internatsionaalses ja piirideta keskkonnas, nagu internetiportaalide kommentaariumid, on iga lausung nii provotseeriv kui ka irooniline, ühest küljest tõsine, teisalt naljakas, ühtaegu teadlik ja teadvustamatu. Järgnevalt analüüsitakse teise nimetusi kontekstis, mis väljendab vaenulikkust või on irooniline, hõlmates seega ka muidu neutraalseina tunduvaid grupinimetusi (venelane, mustlane jne).

Vaenunimi on ajendatud enamasti soovist vastanduda vaenu objektile, teisele (välja arvatud juhul, kui vaenunime kasutatakse omade seas iseenda või heade sõprade kohta, millel on teistsugune toimemehhanism). Teise nimetamine võib olla nii teadvustamatu mänguline tegevus kui ka teadlik ja (poliitiliselt) kontrollitud konstrueerimisprotsess, mille käigus antakse objektidele kontekstuaalseid väärtushinnanguid. Need kaks modaalsust, mäng ja teadlik defineerimine, ei vastandu teineteisele, vaid võivad esineda ka samaaegselt. Võime oletada, et mänguline nimetamine kätkeb pigem positiivset emotsiooni, naudingut sõnamängust, ega hõlma agressiivseid intensioone, samas kui kaalutletud ja poliitiliselt laetud negatiivset nimetamist motiveerib soov teadvustada piire, tuues esile kontraste kahe etnilise grupi vahel. Üldjuhul valitseb üks või teine mudel, ning nende vaheldumine sõltub otseselt erinevatest 
sotsiaalsetest protsessidest ja rahvuse enesemääratlusvajadusest. Kumbki toiming võib kasutada tunnustamiseks ja halvustamiseks samu väljendeid, mille sisu oleneb suures osas kontekstist, ja samavõrra tähendusest, mida konkreetne ütleja sellesse vaenunimesse panna soovib. Seetõttu ongi peaaegu võimatu formaalselt eristada etnilist nimetust ja vaenunime, tähendus peitub eelkõige kontekstis. Näiteks venelane - seda muidu neutraalset nimetust on võimalik kasutada nii positiivses võtmes: Kas Eesti venelased on selles sü̈̈di, et nad siia elama on sattunud? Kas nad on sü̈̈di NL-i kuritegudes? Ei, me ei saa neid sü̈̈distada - samamoodi võiksime ju rusikat viibutada Saksamaa suunas, kuna nemad rõhusid meie esivanemaid. Aga me ei tee seda, see oleks mõttetu (Artur Absull 3.02.2001 13:12:00 \#1981) kui ka negatiivsemalt: ja ja võta võõras venelane maijja hakkab veel vargile, lürbi pärst seda suppi, peksa ka ei saa anda. /.../ (macoy 19.03.2002 9:39:00 \#2465). On ka vaenunimesid, mis selget teenivad üht eesmärki - teise grupi halvustamist, nt tibla: irooniana tere, mjina olen tiibla, isa on varas ja parashiit, eemja on litz, harashoo, pravoslav oleemme (ivan 19.08.2005 12:04:00 \#9642) või ka otsese sõimuna, või kommunismimeelsuse ja tagurlikkuse tähistamiseks ka venelaste poolt: Mis asi on Mari keel? Teil seal eesti keeles peaks olema ikka mari keel. Kas oled tibla või emakeele tunnis ainult kepist unistanud? (vasjok to hmm2 17.08.2005 11:50:00 \#8158).

\section{Tekkemehhanismid}

Järgnevalt kirjeldan lühidalt peamisi tekkemehhanisme, millel allpool Delfi materjali analüüsides ka pikemalt peatun. Vaenunimi ei pea alati olema $a$ priori negatiivse konnotatsiooniga sõna. Kui seda kasutatakse mingi (negatiivselt stigmatiseeritud) grupi tähisena, võib sõna konkreetses kontekstis omandada vaenuliku varjundi. Etnilised vaenunimed võivad olla tuletatud pärisnimest (Ivan - Eestis venelased, Ole ja Lena - USAs norrakad). Teist kirjeldades võidakse kasutatakse igapäevast, neutraalset sõna, kuid muudetakse selle hääldust näiteks matkides vastava grupi aktsenti oma keeles: kahjuks tuleb enne seda jagu saada tiblade perselakkujatest frantsöösidest, hansudest ja onu tomist (abdulla 22.06.2004 9:27:00 \#5645). Sel juhul rõhutatakse vaenuobjekti (teise) mittekuulumist keele- ja kultuuriruumi, gruppidevaheliste erinevuste rõhutamine osutab neile ja kinnitab vastavaid stereotüüpe. Vaenulik võib olla ka rahvuse enda muidu neutraalne nimetus ("ega sa venelane ole, et ...”). Pejoratiivse tähenduse võib anda rahvuse (muidu neutraalsele) nimetusele ajaloolis-kultuuriline kontekst, nt nii mõnegi rahvuse silmis on juut (ainsuses) negatiivne nimetus (nt ta on igavene juut, so ihne, kaalutlev, oma- 
kasupüüdlik vms). Neutraalseid rahvusnimetusi mõjutavad epiteedid, mida nimega kombineeritakse, ning milles omadussõna mõjutab muidu neutraalset rahvusnimetust isegi siis, kui neid koos (enam) ei kasutata. Viimase trendi vastu on ingliskeelses maailmas üritatud siduda terminoloogiat pigem riigiga üldiselt kui isikutega individuaalselt ja võetud kasutusele kombinatsioon rahvuse nimetus (vs rahvuse esindaja nimetus, eesti keeles poolakas vs Poola kodanik) + person: Jewish person. Eestikeelses kultuuriruumis asendatakse vahel poliitilise korrektsuse huvides samuti nt juut terminiga juudi rahvusest, olgugi et tavakeele loomulikkus selle läbi kannatab, ning enamasti kasutata seda mujal kui avalikes pöördumistes või irooniana. Ka eestikeelne mustlane on (eelkõige rahvusvaheliste) keelevaatlejate hinnangu kohaselt negatiivse varjundiga sõna, ning selle korrektsem vaste on romi rahvus. Samas on keeleliselt korrektne kasutada ka tavakeelne väljendeid (õige on nii mustlane, juut, kui ka neeger, mis on küll palju poleemikat tekitanud selle ingliskeelse konnotatsiooni tõttu). Nii selgub põgusast otsingust Google'is, et juut esineb naljasaitidel, kommentaarides, foorumites ja mujal, kus kasutatakse tavakõnele sarnanevat kirjaviisi, samas kui juudi rahvusest on väljend, mida kasutatakse ajaleheartiklites ja muudes avalikkusele suunatud pigem formaalsetes tekstides, kasutamissagedus on aga mõlemal juhul võrdne. Poliitkorrektsuse püüdlus on viinud selleni, et negatiivsetest konnotatsioonidest "puhaste" terminite (inglise keeles code name)välja mõtlemine on tekitanud olukorra, kus võora defineerimise ja nimetamise, mõnel juhul ka vaenamise vajadus võtab järk-järgult kasutusse kõik esialgu korrektsed nimetused ja selle käigus niiöelda saastab need. Kunstlike eufemismide konnotatsioon kõnes muutub aja jooksul iseenesest halvustavaks. See sunnib omakorda leiutama uusi vasteid, kuid eufemismide devalveerumine on sellegipoolest peatamatu. Sama on täheldatud ka teiste stigmatiseeritud gruppide, nt vaimupuudega inimeste kui grupi tähise (akadeemilise > tavakeelse termini) dünaamikas (Cobb \& Rifkin 1991): nt 20. sajandi alguses olid ingliskeelsete teadusterminitena kasutuses idiot, imbecile ja moron, IQ taseme järgi järjestatult; tänapäeval on need muutunud tavalisteks sõimusõnadeks ning teaduskeeles asendatud uute eufemismidega. Polariseeritud nimetuste, ühtaegu eufemismide ja düsfemismide olemasolu on omane teatud nähtustele, nt surm (lahkuma vs lusikat nurka viska$m a$ ), seksuaalsus jms. Suurenenud tähelepanu poliitkorrektsusele on sarnase olukorra tekitanud ka (etniliste jm) gruppide nimetustes, kus rõhutatud korrektsus vaheldub rõhutatud jämedusega (eestivenelane vs tiblaraibe). Ka häbitundel on ühisosa eu- ja düsfemismide kasutamisel, ning häbi ja potentsiaalselt naljaka seiga tajumine (aga ka mittetajumine) seostuvad samuti, ilmselt sarnaselt huumori tajumisega, vähese või liigse inkongruentsustasemega nalja puhul (vt ka Giora 2002). Potentsiaalselt vaenuliku slängi tajumine positiiv- 
se, neutraalse või negatiivsena on kontekstitundlik, nagu ka Nigger on ameerika mustanahaliste seas siseringi släng, väljendades iroonilist suhtumist valgetesse (nt Niggaz with Attitude räp-kollektiivi nimena). Ingliskeelsed rahvusnimetused võivad väikse algustähega kirjutatuna mõjuda vaenulikult.

Aga on ka vaenunimesid, mis on objekti olemuse suhtes meelevaldsemad, lihtsalt tavakõnes negatiivse tähendusega sõnad ( $k \tilde{n}$ ts, jätis = venelane). Osa emotsionaalsemaid vaenunimesid on elementaarsed tabusõnad või nended tuletised ( sitahunnik = homoseksuaal, isatapja ja emavägistaja = venelane). Erinevaid objekte võib nimetada samade väljenditega, kandes vandesõna mõjujõu üle relevantsele objektile.

\section{Vaenunimed ja võim}

Poliitkorrektsus, mille kujunemisaastateks olid 1960ndad Ameerika Ühendriikides, on vähemusrahvuste poliitilise hääle tugevnemisel kandunud sünnimaast kaugele. Sotsiaalsele tundlikkusele rõhuv liikumine on kantud soovist muuta keelt, milles elavad edasi eelarvamuslikkus ja kolonialistlikud vm negatiivsed hoiakud vähemuste suhtes. Võib isegi öelda, et poliitilise korrektsuse püüdlused on kokku langenud etnilise mitmekesistumisega ja globaliseerumisega, ning see on kaasa aidanud uute tabuvaldkondade rõhutamisele: religioosse ja seksuaalse tabu kõrvale on tekkinud etniliste ja sotsiaalsete parameetrite põhjal eristunud gruppide tabunimetused (Hughes 2006). Soovis muuta dominantkultuuri keelt väljenduvad kõige selgemalt vähemuste püüdlused mitte olla ainult formaalselt aktsepteeritud, vaid omada kontrolli nimetuste üle, mida põlisrahvus nende kohta kasutab, omada õigust nimetada iseennast ja oma teisi. Samas võib ka väita, et just selline vähemuste rõhutatud tähelepanu alla seadmine ja eufemismide kunstlik juurutamine kiirendab uute terminite devalveerumist ning dominantkultuuri negatiivset suhtumist sotsiaalsetesse ja etnilistesse marginaalidesse (eriti juhul, kui vähemuste võimutaotlus tundub enamuse arvates ohustavat tema positsiooni).

Arutelud korrektse nimetuse üle on enamasti otseselt seotud kõnealuse rahvuse autoriteetsuse ja mõjukusega rahvusvahelisel areenil, sh postkolonialismi, aga ka postsotsialismi teemaga. Siit jõuame teise olulise teemani nimetamise ja eriti vaenunimede puhul - võimuküsimuseni.

Nimetamine on tegevus, mille käigus antakse objektile nimi, ning mis tõstab subjekti - nimetaja - autoriteedi positsioonile. Nimes on jõud (st sõnas hunt või kurat vms on jõud, s.t sõnas, mitte ainult objektis endas, on jõud, ja seda nimetades saab nimetaja sellest osa). Kellegi nimetamine tähendab autoriteedipositsiooni võtmist, enda seadmist objektist kõrgemale: subjekt on see, 
kellel on võim nimetada objekti oma äranägemise järgi. See muidugi ei tähenda, et nimetamine kui protsess oleks asümmeetriline, tegu on ju elementaarselt inimeseks olemise juurde kuuluva toiminguga, mis eksisteerib igas ühiskonnas. Vaenunimede loomise ja kasutamise intensiivsus võib aga rühmiti erineda, kuigi võib ka interaktsioonis enamasti võimenduda/teravneda. Sama mehhanismi on võimalik seletada kognitiivse dimensiooni infotöötlusfunktsiooni abil, sest nimetamise kaudu allutatakse võõras oma mõttemallile, üritatakse mõista (või mittemõistmise korral distatnseeruda), lahterdada. Nimetus tõstab esile vaid teatud aspekti, jättes varju muu, mis omakorda toimib välismaailma lihtsustava protsessina, kuid ühtlasi surub objektile peale tema seisukohalt võõrad raamid. Nimetuse valik oleneb intensioonist - nt venelastest rääkides kasutab nimetust tulnukas see, kes lahkab immigrandiprobleeme, tibla aga see, kes räägib ajaloost, kommunismimeelsusest või tagurlusest. Esimene neist jätab varju negatiivsed emotsioonid, kuid rõhutab venelaste kui rahvuse äärmusse kalduvat võõrust, kes on "tegelased teiselt planeedilt", ebahumaansed ning hirmuäratavadki. Tibla on tuletislaen venekeelsest vandeväljendist ты, блядь, mis on kaotanud oma algse seose vägisõnaga ja omandanud lisatähenduse kontekstis/ ühiskonnas, kus tibla väljendas Eesti okupeerimist võõrvägede poolt ja kommunistlik-totalitaarset poliitkat.

Ka poliitikas ja tänapäevases meediakontekstis on nimetamine oluline osa diskursuse loomisest. Sellest, millised on avalikult aktsepteeritud nimetused, võib näha trende interentilistes või gruppidevahelistes suhetes. Kuigi siia alla kuuluvad ka vaenlast (nt terrorism, immigrandid, ka rassism) tähistavad nimetused, piirdutakse käesolevas artiklis vaid internetislängi uurimisega.

\section{Vaenunimede sotsiaalsest dünaamikast}

Etnilised vaenunimed tekivad eelkõige kiirete sotsiaal-poliitilis-majanduslike muutuste ajal, mil etnilised grupid tunnevad ennast ja oma staatust ühiskonnas ohustatuna. Immigratsioon, linnastumine, sellega kaasnevad sotsiaalsed probleemid nagu tööjõupuudus, varanduslik kihistumine jms loovad soodsa pinnase võõra identifitseerimiseks. Ka Irving Alleni (1983) põhjalik uurimus etnilistest vaenunimedest USAs ja Suurbritannias osutab vaenunimede kasutamise otsesele seosele konfliktsituatsiooniga, eelkõige vastuoludega sotsiaalse staatuse tasandil (immigrantide staatus põliselanike suhtes). Kuigi vaenunimed eksisteerisid ka sajandeid tagasi (eelkõige kohalike etniliste gruppide kohta, sest kontakt välismaailmaga oli väike), andis kindla tõuke sellealase sõnavara täienemisse kindlasti üleilmastumine. Nii näeme vaenunimede arvu kiiret kasvu Euroopas näiteks aastatel 1880-1930 (Allen 1983: 2). Eesti ja kogu 
Ida-Euroopa saatus 20. sajandi ajaloos on tinginud selle, et siinsed rahvused tunnetavad väga teravalt iga potentsiaalset ohtu nende rahvusriigile, ning idealistlikud-patriootilised püüdlused satuvad vastuollu majanduslike ja poliitiliste kaalutlustega nii üksikisiku kui ka riigi tasandil. Osa ühiskonnast suhtub immigratsiooni seetõttu negatiivselt ega usu rahumeelse kooseksisteerimise võimalikkusse. Ka paljud Ida- ja Kesk-Euroopas teostatud longitudinaalsed rassismi-ja ksenofoobiauuringud näitavad, et võõraviha on postsotsialistlikus ühiskonnas levinud (mõne uuringu kohaselt ka sagenev) nähtus (vt Mudde 2005). Selle oluliseks kujundajaks on kommunikatsioon avaliku ja isikliku ruumi vahel. Paljudes postsotsialistlikes maades on olnud tugev vastumeelsus sõnavabaduse piiramisele, mis poliitilist minevikku ja poliitikute valimisplatvorme arvestades pole sugugi üllatav. Samas on kõik kõnealused riigid ühinenud kõikide oluliste rassismivastaste konventsioonidega, kriminaliseeritud on ka vaenukõne ja vaenule õhutamine. Vaid üksikud juhtumid on jõudnud tegelike kohtulahendusteni, sageli karistatakse vaid vägivallaakti, arvestamata selle rassistlikku meelestatust; selles osas on Lääne-Euroopa uutest liikmesriikidest kaugel ees. Rassistlike vägivallaaktide esinemissageduse järgi on uutest riikidest parim olukord Balti riikides ning halvim on seis Bulgaarias, Tšehhimaal, Ungaris, Poolas ja Slovakkias (ründeobjektiks enamasti rahvusvähemus mustlased). Ida- ja Kesk-Euroopa poliitikute rassismivastased väljaastumised on piirdunud tõsiste vägivallajuhtumite taunimisega, mille eesmärk on kõnetada pigem rahvusvahelist avalikkust kui vastava riigi kodanikke. Ka Interneti kaudu propageeritav võõraviha on probleem, mille vastu võitlevad erinevad uusliikmed eri aktiivsusega: mõnes riigis on internetiteenuse pakkujad (ISP) koostööaltimad (nt Tšehhis ja Ungaris) kui teistes (nt Poolas). Samas on rassistlikel liikumistel alati võimalus "kolida" teise teenusepakkuja juurde, enamasti Venemaal või USAs. Usuliikumised üldiselt rassimivastasest võitlusest osa ei võta (erandiks ehk Lääne-Euroopa, kus neil on täita aktiivne roll tolerantsuse propageerimisel), võimalik et nad propageerivad siin isegi rassistlikke suundumusi (Rumeenia ja Slovakkia õigeusukirik, Poola katoliku kirik, aga vt ka Eesti kristliku foorumi analüüsi, Laineste 2008, ilmumas). Mõned uurijad on arvamusel, et majanduslikud ja kultuurilis-ajaloolised seosed riikide ja immigrantrühmade vahel ei seleta pidevalt muutuvat ksenofoobia taset, millest võib järeldada, et peale vastastikuste suhete ajaloo ja demograafiliste näitajate tingivad rassismi ka muud mõjurid. Viidatakse, et oluliseks mõjuriks võib olla meedia, poliitikute suhtumine ja muu kommunikatsioon avaliku ja isikliku ruumi vahel (vt Nyíri 2003). Trükimeedia, poliitilise diskursuse ja argisuhtluse retoorika sisaldab varjatud päästikuid ja suunajaid, mis kinnitavad olemasolevaid ja loovad uusi oma ja võõra eristusi (Žagar 2002). Sageli kujutatakse immigrante ning rahvus-, religiooni- jm vähemusi kontekstis, mis rõhub emotsioonidele, kasutatakse negatiivseid kujundeid, kriminaliseeritakse, 
marginaliseeritakse ja mütologiseeritakse, ning selle käigus luuakse omadest kannatajakuvand. Postsotsialistliku ksenofoobia põhitunnuseks on see, et kuigi ollakse kursis poliitkorrektsuse nõuetega, üritatakse kaudselt õigustada oma rahvuse ksenofoobiat ohvrisündroomiga, viidates enesekaitsevajadusele. Kui Lääne-Euroopa õppetunniks on olnud tema minevik kolonisaatorina, mis süükompleksi kaudu sunnib vastutustundlikult suhtuma ka immigrantidesse, siis Ida-Euroopa oma ja võõra vastandus on kujunenud vennalikus idablokis ning sellest tulenevalt on idaeurooplaste identifitseerumisvajadus ka avaliku ruumi retoorikas esikohal.

Internetis on vaenunimede kasutamine üsna tavapärane. Internet on uus meedia, millel on nii verbaalse kui ka kirjaliku kommunikatsiooni puudused ja voorused: tegu on nii “õhendatud" kui ka "lisandatud” kvaliteediga (vt Danet 1991). Sama näeme vaenunimede analüüsis. Ühest küljest on tegu "õhendatud" meediumiga, mis tundub piisavalt verbaalne, et öeldut võiks tajuda kui igapäevakõnet, mis kannatab ka negatiivseid väljendeid, seda enam, et ütlejat kaitseb kas anonüümsus, või toimub virtuaalne keskustelu näiliselt suletud sõprusringis. Teisalt on Internet siiski kirjalik "lisandatud" meedium, ning kirjapandu jääb küberruumi püsima, vähemalt senikaua, kuni seda pole "avastatud" ja tsenseeritud, teiste (solvatud) kasutajate poolt kustutatud vms. Enamasti on vaenunime evolutsiooni algpunktiks suulises vestluses lausutud näiliselt tabav ja uudne väljend või vana slängi teravmeelne modifikatsioon, mis aja jooksul imbub ka kirjalikku teksti. Tänapäeval on selle tsükli pikkus oluliselt lühem kui enne Internetiajastu algust, võib isegi öelda, et paljudel juhtudel on tegu sünkroonse tekke ja arenguga. Samas on selge, et kirjaliku kõne mõju on oluliselt tugevam, jäävam ja autoriteetsem kui see, mis käib kaasas suulisusega. Pejoratiivse sõna kirjapildil on konventsionaliseeriv ja kinnistav efekt.

\section{Analüüs ja arutelu}

\section{Valim}

Vaatluse all on Delfi Eesti-uudiste kommentaarid aastatel 2000-2007 (vastavalt nädalad 2000: 47, 2001: 5, 2002: 12, 2003: 19, 2004: 27, 2005: 33, 2006: 40 ja 2007: 2 ning 2007: 21). Valimis on iga nädalapäeva kaks populaarseimat ehk enim kommentaare kogunud uudist rubriigist Eesti, kokku on artikleid 91 ning analüüsitud kommentaare 18 382. Delfi kommenteerijad ei pea olema registreeritud, kommentaatori isik jääb anonüümseks, samuti saab vabalt muuta nime, mille all kommenteeritakse. Nimed on sageli väga muutuvad, seotud nt artikli teemaga. Vaid üksikud kasutavad aastaid sama nime (Zebra, Veli- 
rand); seda teades kasutavad anonüümsed kommentaatorid vahel nö tuntud tegijate nimesid (enamasti selleks, et nende seisukohtadele vastu rääkida, seisukohta seestpoolt õonestada), mis juhib tähelepanu päris- ja pseudokommentaaride probleemile. Eriti aktuaalne on see Delfis, kuid nähtav ka muudel saitidel, kus irooniana tõlgendatav kommentaar propageerib mingeid seisukohti, mida kirjutaja ise ilmselgelt ei poolda. See omakorda näitab ja ka kinnistab Delfi olemust anonüümse massi kommentaariumina, milles julgustatakse tsenseerimatut väljaelamist ja kus puuduvad sisemised (kommuuni)reeglid, ranged piirid lubatu ja lubamatu vahel. Aruteludest võtavad aeg-ajalt osa ka eestivenelased (nähtav kirjaviisist või vigadest ja kaaskommentaatorite reaktsioonidest). Keskkonna iseloom iseenesest, sh anonüümsus, aga ka kasutatavus ja populaarsus, mõjutab keskkonnas viibijaid.

\section{Meetod}

Andmete analüüsiks kasutati kvalitatiivseid ja kvantitatiivseid meetodeid kombineerivat andmetöötlusprogrammi QDA Miner 3.0. Juhuslike nädalate valimisega välditi võimalust, et valim oleks kallutatult ja rõhutatult rassistlik. Kui võtta valimisse perioodid, mil ühiskonnas toimus mõni tegelik ksenofoobiat õhutav sündmus (pronksiöö, WTC jne), oleksid reaktsioonid võimendatud ja pilt kommentaaride iseloomust kallutatud. Kodeerimispõhimõtetega saab tutvuda Lisas 1, kus on välja toodud nii koodid kui ka näited igasse kategooriasse liigitatud tekstide kohta. Kodeerimissüsteem töötati välja proovikodeerimise käigus, mis hõlmas umbes 500 kommentaari erinevatest valimiperioodidest. Kommentaarid, kus agressiivselt väljendudes astuti välja diskrimineerimise vastu (agressiivne antirassism jms), jäeti kodeerimata kui uurimuse teemasse otseselt mittepuutuvad. Kodeerimisjuhendisse on märgitud siinkohal ainult käesolevasse uurimusse otseselt puutuvad või siin viidatud kateooriad, täieliku juhendi ja ülevaatlike uurimistulemustega on võimalik tutvuda peatselt ilmuvas justiitsministeeriumi kogumikus Rassism ja ksenofoobia Eestis (Laineste 2008). Kvalitatiivne analüüs hõlmab vaenunimede konteksti analüüsi, mille kaudu omandab nimetus enamasti valentsi, ja valitud vaenunimede tekkemehhanismi analüüsi.

\section{Vaenunimed}

Kõigepealt kirjeldame kõige sagedasemaid vaenunimesid, mida internetikommentaatorid kasutavad. Loetelus on ära toodud nimetused, mis esinesid materjalis kolm korda või enam. Vaenunimede sagedusstatistikat (joonis 1) uuri- 
des näeme, et suurim osa neist käibib venelaste kohta, kuid ka homoseksualism ja usklikkus ärgitavad kommentaarides negatiivseid nimetusi kasutusele võtma. Kuigi mustlane ja soomlane on joonisel 1 sagedamini vaenukõneline kui mustanahaline, jäeti need detailsemast loetelust välja, sest mõlemal juhul oli tegu vaid ühe spetsiifilise uudisega (vastavalt "Teller varastas mustlasele pool miljonit", 5. 10. 2006 ja video "Soomlased põletavad Eesti lippu", 11. 1. 2007), mis negatiivseid nimetusi inspireeris, ning tegu pole aktuaalse ja kinnistunud nimetuste/ suhtumisega.

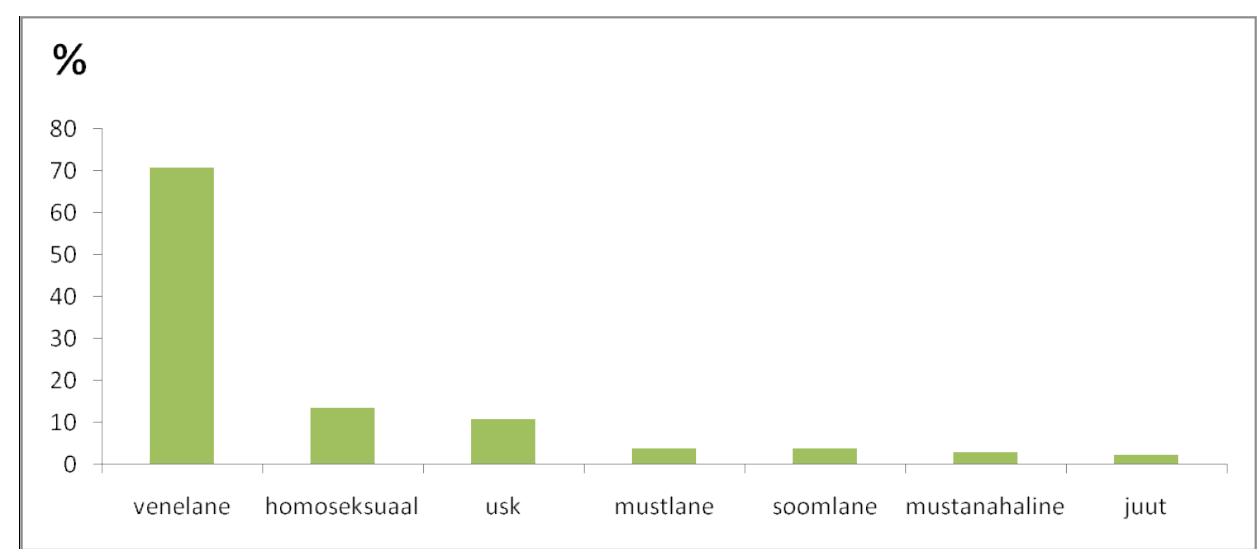

Joonis 1. Vaenunimede sagedasimad sihtmärgid Delfi päevauudiste kommentaarides aastail 2000-2007.

Venelane (et venelaste-kohaseid vaenunimesid oli suurim hulk, on tulemused ülevaate lihtsustamiseks kategoriseeritud viide tinglikku alaliiki): (1) nimed, mis seostuvad Venemaaga, sh osutavad rahvuse geograafilisele asukohale eestlaste suhtes (venemaalane, suurvene rahvas, russkije, Russian, slaavi, russ, moskvitsh, ryssä, Moskvast, moskooviast, idast, idapiiri tagant, tiblastanistist, VF kodanik, Lasnamäelane); (2) mittespetsiifiline sõim (rämpsrahvas, kõnts, närakad, kaak, tõbras, kaabakas, jobu, raisk, (venekeelne) joodik / pätt, vene (uus)nats, loll rahvas, (vene) siga, tölpa, kumõssinägu, (vene) maffia); (3) kommunistlikule minevikule viitavad nimetused (communist, kommu, komsomoli tegelane, kommar, kgbeesnik, okupant, kommunistist rahvavaenlane / mõrtsukas, vallutaja, kolonist, nn vabastaja, punalumpen, punakrae, punaterrorist, kommupeer); (4) negatiivsed hüüdnimed (venku, venkar, tiblaraibe, tibla, tiblasõdur, tiblunn, tiblahakatis, tiblanolk, tibluush, vaanjuška, vanka, vasja, ivan, ivan-poiss, sibulakasvataja, sibul, sebra/sebrakari (Delfi-spetsiifiline, viitab ühele sagedasele vene rahvusest kommenteerijale), masha ja sasha, sihvkasööja, 
vant, vene karu, mužikk ja baba, Kukusha, puhvaikas tegelane, žurik); (5) nimetused, mis väljendavad venelaste olukorda Eestis (muulane, vähemus, välismaalane, külaline, rahvusvähemus, muukeelne, eestivaenulik vähemus, immigrant, tulnukas, humanoid, kutsumata külaline).

Üldjoones võib variatiivsuse ja arvukuse põhjal öelda, et kõige enam kasutatakse nn negatiivseid hüüdnimesid, millel pole konkreetset poliitilist vm tausta (vs geograafilisele päritolule või immigrandi staatusele viitavad nimetused) ja milles tähelepanuväärne osa on halvustava hüüdnime tibla variatsioonidel. Mittespetsiifilist sõimu, mille objektiks võib teoreetiliselt kohandada ka iga teist gruppi, esineb harvem. Negatiivsete hüüdnimede sage kasutamine on igati ootuspärane, eriti arvestades meediumi omapära: siia ei tule need, kes on tõsiselt huvitatud päevapoliitilisest arutelust, vaid pigem need, kes otsivad meelelahutust, naudivad vaidlust iseenesest, lasevad auru välja. Kommenteerijad kasutavad kujundlikku vaenunime neutraalsete väljendite ees, luues sellega kontrasti oma ja võora vahel. Ka neutraalsete nimetuste puhul on kontekst see, mis iroonia või vaenuliku sisu kaudu muudab sageli negatiivseks ka poliitkorrektsed tähised (nt kateooriatest 1 ja 5).

Homo: emane, pede, pederast, gay (gei), seksuaalvähemus, omasooihar, poistepilastaja, inimjälkus, pervert, hälve (hälblane), sitahunnik, libeda tukaga poiss, meeste pruukija, ebanormaalne, väärakas pede, poolearuline debiilik, lilla, Angeli publik, vikerkaarevärviline, kommionu, homoaktivist, piider, sitaimeja, anaalhoor, pepuvend, poistearmastaja.

Ka selle rühma puhul on valikute arv suur, kuid venelase-nimetustega võrreldes on homod stigmatiseeritumad ja valdav enamus nimetustest kuulub halvustava sõimu kategooriasse. Kuid ka siin on poliitkorrektseid termineid (seksuaalvähemus) või siseringiväljendeid (gei), mida kontekst aitab muuta negatiivsemaks. On uudiseid, mille puhul kommenteeritakse homoseksuaalsust koos usklike, aga ka venelastega, mispuhul tekib omalaadne vihahierarhia.

Mustanahaline: neeger, tõmmu, negroidsete joontega, kannibal, neegrionu, aafriklane, brikett, mustukene, nõgi.

Diskussioon, mis paneb inimesi selle teemaga seoses alati arvamust avaldama, on mustanahaliste korrektse nimetamise küsimus. See on ühtlasi ilmekas näide selle kohta, kuidas poliitkorrektsus võib oma eesmärki mitte täita või koguni selle vastu töötada: nimetuse neeger vastased tõmbavad oma tegevusega selle Eestis peaaegu olematu rühma peale teenimatult negatiivset tähelepanu, mis väljendub eelkõige vihas, et üks huvirühm üritab kontrollida eesti keelekasutust. Meelepaha laieneb aga sujuvalt vastasseisuks immigratsiooni, võõrtööliste jm suhtes.

Usutegelane: kirikusaks, usuvürst, jessukese jünger, mustakuuemees, ristikoer, usuhull, usufanaatik. 
Usuga seotud küsimustes on kommentaatorid üllatavat vaenulikud ning seostavad usku väga selgelt silmakirjalikkuse, fanatismi, kitsarinnalisuse, pedofiilia jm seksuaalkuritegudega. See on muuhulgas seotud sõnavõtjate rahvusliku meelestatusega, mille kohaselt peaks rahvuslik usk olema kauge kristlusest jm vägivallaga toodud usunditest.

Vaenunimede tekkemehhanismid kuuluvad kahte põhikategooriasse, mida ka teooriaosas puudutati: esiteks on vaenunimetusi, mis omandavad negatiivse tähenduse alles kontekstis, teised aga kannavad tabu- ja vandesõnade või negatiivse võrdlusena juba niigi halvustavat tähendust. Kõigepealt käsitleme eufemismide ja neutraalsete nimetuste muutumist vaenunimedeks. Eufemisme või tavatähenduses neutraalseid nimetusi võib muidugi leida ka marginaalselt vähestes pooltkommentaarides:

Siinsetes kommentaarides lehkab nii vaenu järele kui ka mõistmatust ja viha teiste kultuuride suhtes! Kahju, et eestlased nii paganama kadedad ja õelad! Veidi rohkem võiks olla lugupidamist / ... / muude eestimaalaste suhtes! (Mark Valdma 10. 01. 2007 11:08:00 \#13374)

RASSILINE KUULUVUS EI MÄÄRA RAHVUST! Mul pole midagi näiteks mustanahaliste v6i mulattide vastu kui nad muidu kenad ja eestimeelsed inimesed oleksid. Rassiste ma kyll inimsuse eesrindlasteks ei pea (Atman 18. 03. 2002 13:16:00 \#2295).

Enamasti aga antakse eufemismile just iroonia kaudu teravalt vaenulik varjund: jummal jummal. kus viimasel ajal on ikke lolle pinnale ujunud... teha tegemist inimesega kelle nahavärvi kood on miskit muud kui hele on suisa enesetapp. ja minna veel vangi ka sellepärast et loll oled!? ei noh (macoy 5. 10. 2006 14:38:00 \#11961). Moonutused võivad eufemismi devalveerida: Neli kõva asja - sakslase püss, soomlase puss, eestlase jonn ja venelase m... Nii et “jeestimaalased" päästavad hädast välja (W 31. 01. 2001 19:44:00 \#1636). Mõnes kommentaaris on näha eufemismihierarhiat, nt järgnev näide peab terminit muulane ilmselt positiivsemaks ju ka iseeneselikult (kirjutaja silmis) negatiivsemast venelasest: kui praegu valib iga eestlane omale sobivaima tunduva variandi, siis muulane (loe:venelane) teeb seda sama ja ma ei imestaks, kui nii oleks varsti võimule veelgi lähemal endised KGB tegelinskid (PrimeFun 29. 01. 2001 17:28:00 \#1016). Kontrasti luuakse ka venelase ja venelase vahele: rahvuse kohta on üks nimi, kuid elupaik määrab, kas temasse peaks suhtuma halvakspanuga või mitte: venelane, st Venemaal elav vene inimene, kelle ajusid ei ole niipalju nüristatud, kui kohaliku Lasnamäe seltsimehe omi, ei pruugi sugugi sama loll olla, kui Sina, venelane (lugeja 9.05.2003 21:44:00 \#5019). 
Kõige puhtam nimetuse metamorfoos toimub aga siis, kui rahvusnimetus ongi iseenesest vaenunimi, ilma epiteetide või lisaselgitusteta, nt järgmises kommentaaris: sa valge jüri oled ikka eriline asi küll.Ju sa juut või venelane oled (karv 16. 08. 2005 14:04:00 \#7872).

Uute ja sageli üsna suvaliste vaenunimede teket iseloomustab Delfi-spetsiifiline vaenunimi Sebra, mida kasutatakse venemeelsete, tülikalt väitlevate kommentaatorite või ühiskonnategelaste puhul, nt pärast tahaks zebrajobu näha.Hämmastav kui palju aega on inimesel, kommentaare tuleb nagu sebral sitta (huvi 3. 10. 2006 19:38:00 \#11303), ja mida saab kasutada tuletissõnades: jälle sebrakukk kiremas (oho 17. 08. 2005 ... 12:44:00 \#8177). Venelaste kui teise nimetamise puhul on selge üleminek ja eristus neutraalsema venelase ja halvustava tibla vahel, ning selle kaudu jõuame vaenunimede teise tekkemehhanismi kirjeldamise juurde: kuidas tabusõnu jms kasutatakse teise tähisena.

Tibla on tabusõnaline vaid etümoloogialt ja tänapäeval küll halvustav, kuid mitte enamasti agressiivne:

Kaos saabub maale, siinsete tiblade järglased pole eestlaste moodi tööinimesteks loodud, nende vanemad tulid meie maale just saamameestena, mitte oma tööpanust lisama ja nende järglased on väärilised järglased. Viina, narkotsi ja tubakst, muu neid ei huvita, eelmisest suvest mäletame ühte juhtumit, kus eesti keele õppimise asemel õpetas üks tatikas pererahva lapsed vene keeles ropendama ja see oligi kogu tulemus. Kel võimalik, hoidke neist eemale, nii kaugele kui vähegi annab (klemm 19. 03. 2002 8:09:00 \#2453).

Sellest oluliselt vaenulikumad on seksuaalse või skatoloogilise sisuga tabusõnad: Küll pronksmunn peale valimisi lendab, kui enam kesk valitsusse ei pääse. Laar tuleb ise bazuukaga, paneb savipätsi pildi sinna ja tulistab pasa tükkideks (VC 10. 01. 2007 18:58:00 \#13454) või sulle sitasonkijale tuleks türa kurku lü̈̈a, et keel enam ringi ei käiks.suu on söömiseks ja perse sittumiseks.VÄ̈̈RAKAS (to sipsik 15. 08. 2005 18:23:00 \#7294).

Kasutatakse ka vähem emotsionaalseid, universaalselt negatiivseid sõimusõnu: ma ei ole ugri, aga sellegipoolest pean sinu jutule reageerima. Sinusugused on loodud olema alam rass ja ugrilasi teenima, oma suguliikmeid aga me sinusugustega ei rüveta, tee seda omasuguste sigadega. Minu suurim soov on aga sinusugustele MG 3st lint kõhtu tühjaks lasta... (Eestlane 19. 03. 2002 11:19:00 \#2512) või kui seda Tartu lepingut ei oleks, oleks meil täielik alus sinusugust vastalist koera laternaposti otsa kaelapidi tõmmata kuivama... (vaata sk... 20. 03. 2002 14:38:00 \#2876). 
Vaidlused, millest võtavad osa mõlema poole esindaja (nt eestlased ja venelased), lähevad sageli teravaks ning seal leiavad hulgaliselt kasutust nii tabukui ka sõimusõnad.

\section{Vaenunimede kontekst}

Suurim osa kommentaaridest sisaldas vaenunimesid juhul, kui uudises figureeris mustlane. Ka mustanahalisi ja homoseksuaale mainivate uudiste kommentaarides nimetati vaenukõne objekti sageli negatiivse slängiväljendiga. Need on kolm peamist rühma, kelle nimetamiseks valiti peaaegu alati negatiivse konnotatsiooniga slängisõna neutraalsemate ees. Venelaste kohta on küll kõige arvukamalt erinevaid vaenunimesid, kuid kasutati ka neutraalsemaid nimetusi (nt vene rahvusest, venelane, suurvene rahvusest jms). Seega pole venelaste puhul vaenunimede kasutamine proportsionaalselt (vaadeldes vaenunimede osatähtsust kõigi vaenulike kommentaaride seas) nii aktuaalne kui mõne teise rühma puhul (peamiselt mustlased, mustanahalised ja homoseksuaalid). Oluliseks mõjuriks on see, et mustlasi halvustavaid kommentaare on iseenesest üsna vähe, samas venelase kui vaenukõne objekti puhul domineerivad lihtsalt teised kategooriad (sõim, negatiivsed stereotüübid, erimeelsused ajalootõlgenduses jms).

Kõige sagedamini esinevad vaenunimedega ühes kommentaaris sõim $(\mathrm{J}=0,043),{ }^{1}$ aga ka samaaegsed üleskutsed rünnakule $(\mathrm{J}=0,038)$, grupi negatiivne mõju ühiskonnale $(\mathrm{J}=0,033)$ ja vaidlused ajalootõlgenduste üle $(\mathrm{J}=0,032)$; vaenunimede kasutamine teiste kodeeringute kontekstis oli harvem.

Seda, millistes kommentaarides vaenunimesid sagedaimini kasutatakse, mõjutavad kõige ilmsemalt esiteks uudise provokatiivsus ja teiseks kommenteerijatevaheline vastasseis (mille teravus oleneb omakorda sellest, kas diskussioonist võtavad osa kõnealuste rühmade mõlemad pooled, nt nii venelased kui ka eestlased). Kui keskmine vaenunimede osatähtsus kogu valimis oli 0,8\%, siis mõne uudise puhul kerkis keskmine oluliselt kõrgemale. Uudised, mille puhul üle 6\% kommentaaridest sisaldas vaenunimesid, olid näiteks "Venelaste arvates astusime vabatahtlikult N Liitu" (8,2\%), "Palts: Gayliit võtku Lepikson oma liikmeks" (7,8\%), ja "Pronkssõduri lõpu algus" (6,6\%). Enim vaenunimesid sisaldanud artikli kommentaarid on tingitud uudise ajastatusest: 21. mai 2007 oli eestlastele rahvusküsimuses ülitundlik aeg. Uudises on varju on jäetud asjaolu, et refereeritud uurimus tehti juba aastal 2005, mis viitab ilmselgelt Delfi toimetajate soovile ära kasutada kommenteerijate emotsioone. 
Väga oluline roll on kommenteerijate vaadetel ja nende väljaütlemise viisil: nt Gayliitu puudutava uudise kommentaarides võttis sõna mitu inimest, kes jutlustasid tolerantsuse vajalikkusest üsna agressiivsete sõnadega:

Niisama julmalt ja rõvedalt, nagu vähemusi, kohtleb haige Eesti ühiskond ka teisi nõrgemaid, vanu inimesi, puuetega invaliide, ühesõnaga KÕIKI, kes julgevad milleski ERINEDA või vajada abi. Viletsad ja väetid olete, teis paljastuvad tõeliselt väikesed inimesed ja seda vaimse tühjuse mõttes (Sipsik 15. 08. 2005).

Et see teema seostub rahvuslusega, võtsid ka siin sõna eestimeelsed inimesed, kelle silmis homoparaad on rahvuse allakäigu tunnus: Aga kas eesti rahva arvu peale ka mõtlesid,või ainult oma mõnudele? (halb? 15. 08. 2005). Vastasseis tekitab nii mõnegi terava ja isiklikuks kippuva olukorra: Sitahunnik keset tänavat ei tee ka midagi halba, aga vaata - ei meeldi...., sest tema õige koht on peldikuaugus! Vot nii, sitaaugu-sass! (to Ahh, 15. 08. 2005), ja vastusena sellele Sitahunnik on üks väga kasulik asi,kuna shitt annab rammu!Ilma sitata ei kasva midagi.Nii nagu homod, nii ka sitahunnik on mõlemad ühiskonda toitvad ja viljastavad nähtused (undu to to ahh, 15. 08. 2005). Vaenunimede kasutamine oleneb niisiis suuresti kontekstist: milline oli uudis, mis kommentaare ajendas, kes olid kommenteerijad, millised olid uudise (kõrval)tegelased, aga ka ilmumise laiem sotsiaalne kontekst jne.

Vaadates vaenunimede kasutamise ajalist dünaamikat Delfi uudistekommentaarides (joonis 2 ja joonis 3), näeme kõrgtaset aastal 2003 ning selle järel langust, mis kestab ka pärast 2007. aasta kevade sündmusi (pronksiöö). Vaenunimede osatähtsuse vahepealset tõusu saadab teiste tugeva agressiivsusega

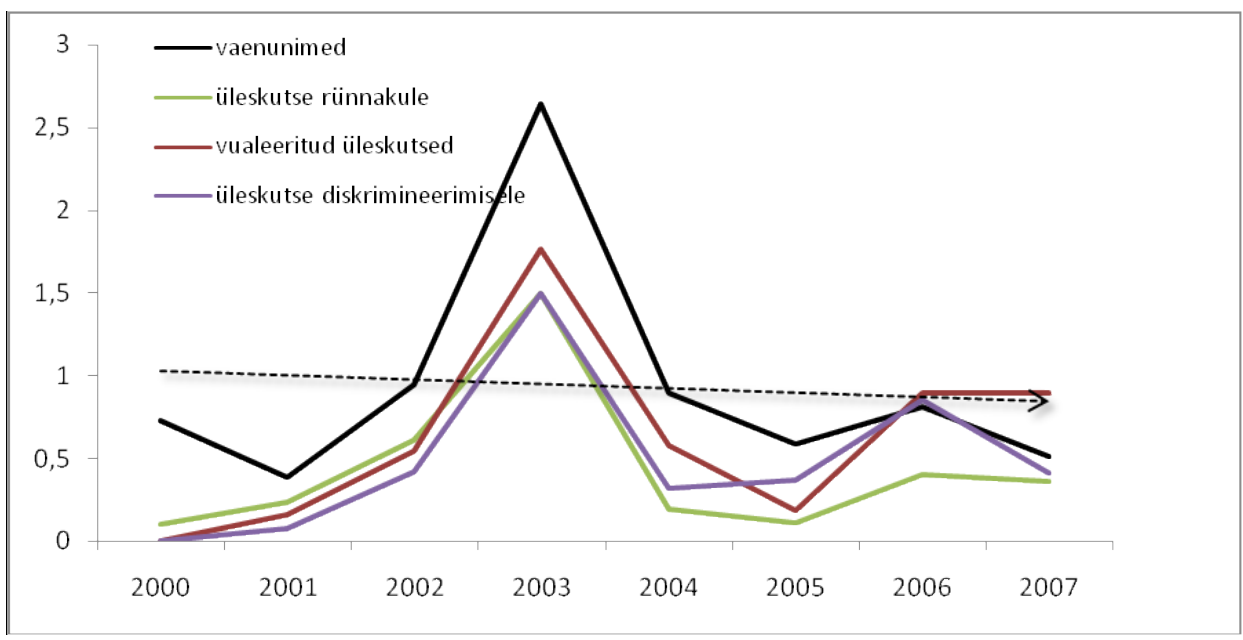

Joonis 2. Langevad trendid vaenukõnes: suure agressiivsusega kommentaarid Delfis. 


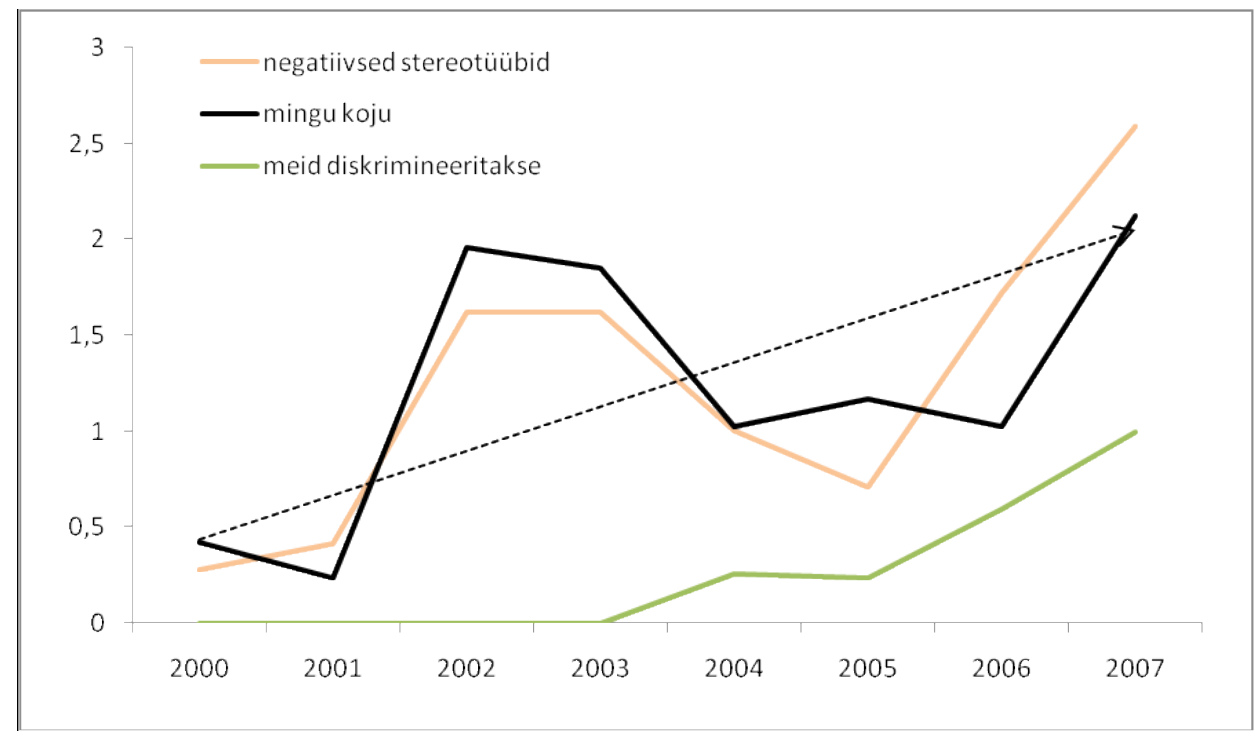

Joonis 3. Tõusutrendid vaenukõnes: vähese või keskmise agressiivsusega kommentaarid Delfis.

kategooriate esinemise sagenemine, mis on põhjendatav nii uudiste suurema provokatiivsuse kui ka rahvustunde tugevnemisega sellel perioodil (detailsemalt vt Laineste 2008). Vaenunimede, sõimu ja otseste või looritatud (vualeeritud) üleskutsete asemel kasutavad kommenteerijad pigem negatiivsete stereotüüpide refereerimist, kurtmist teiste-poolse diskrimineerimise üle ja soovitust kõigile immigrantidele või mitmenda põlve sisserändajatele minna tagasi oma kodumaale. Trendiks on seega nimetada teist neutraalsema nimega kui varem ja teda pigem süüdistada (elukeskkonna halvenemises vms) kui agressiivselt rünnata. Tulemust mõjutab fakt, et kommentaare on 2003. aastaga võrreldes oluliselt rohkem ja kuigi suur osa Interneti-kasutajatest kasutab pigem neutraalseid nimetusi, siis langenud on vaid osatähtsus, absoluutarvud on isegi tõusnud.

\section{Kokkuvõte}

Käesolev uurimus keskendus internetikommentaaridele, mis sisaldavad vaenunimesid ning teisi rahvustevahelist vaenu õhutavaid väljendeid, et selgitada välja eestlaste teise nimetamise mustrid ja arutleda selle võimalike põhjuste üle.

Etniliste rühmade kohta käibivad slänginimed täidavad ühiskonnas sotsiaalsete piiride markeri rolli. Ka käesolev analüüs näitas, et kommenteerijad män- 
givad vaenunimede loomisel normaalsuse ja ebanormaalsuse, õige ja vale, hea ja halva jt aksioloogiliste kategooriate piiridega. Defineerides oma (vahel äärmuslikku) eestlust, vastandutakse tibladele, pededele ja teistele näiliselt normivälistele rühmadele. Jõupositsiooni saavutamiseks teatud keskkonnas märgistavad ühe rühma esindajad teisi kui alaväärseid, veidrate kommete ja musta minevikuga ohtlikku kontingenti, keda tuleks "õigesti nimetades" paika panna. Informaalse kontrolli mehhanism toimib ka Interneti-kommentaarides: nagu hüüdnimed toimivad väikestes sotsiaalsetes rühmades, nii toimivad vaenunimed ühiskonna tasandil.

Ajaloolised uurimused vaenunimedest (nt Allen 1990, Hughes 2006) täheldavad, et nt USA 19. ja 20. sajandi alguse etniline sõim oli tugevama emotsionaalse laenguga kui tänapäeva slängiväljendid võorra kohta. Pealtnäha süütud väljendid levivad tänapäeval igapäevavestluses, meedias, avalikes kõnedes jm. See legitimeerib negatiivse varjundiga väljendeid ja ühest küljest vähendab vaenunimede teravust (korratakse neid ju rohkem, ja seegi vähendab sõna "väge"), teisalt aga toimub selle abil nimetuste populariseerimine, ja mõne teooria kohaselt ka kinnistumine (nt Maio et al 1997, Hobden et al 1994, Billig 2005). Orwell (1946) on öelnud essees inglise keelest ja meelest, et mitte ainult mõte ei mõjuta keelt, vaid ka vastupidi (seda uurisid ka lingvistid 1930. aastatel, nt Whorf, Sapir jt) - mida rohkem kuuldakse negatiivseid hüüdnimesid, seda rohkem me neid kasutame, usume ja aktsepteerime. Halb komme levib imiteerides, väidab Orwell, kuid lohutab samas, et teadvustatud kõnelemine on esimene samm meele, so hoiakute, muutmisel. Ka vaenunimede teaduslik analüüs eeldab nimetamist ja kirjeldamist, mis jällegi taastoodab võóravaenu, kuid teisalt on see vajalik, näitamaks, millised on tavakeele mõjud, needsamad kombed / halvad harjumused, mis negatiivseid nimetusi levitavad, ning osutab, kuidas võib poliitilise konflikti vältimine või taltsutamine sõltuda keelest, mida me iga päev kasutame. Samuti kirjeldab etniliste vaenunimede uurimine rahvusideoloogia ja etnilise märgistamise tagamaid, lisades sotsioloogide etniliste hoiakute jm kvantiteetuuringutele kvalitatiivse mõõte. Loomulikult pakuks selle teema käsitlusele olulist täiendust inimeste ettekujutuste uurimine: mida inimesed arvavad vaenunimedest, nende igapäevasest kasutamisest, ja mil määral on see teadvustatud. Etniliste vaenunimede mõju tegelikule käitumisele peaksid välja selgitama sotsiaalpsühholoogilised käsitlused, kuid selleteemalisi teadustöid pole just palju (Mullen 2002: 458). Vaenunimede, nagu ka huumori puhul on raske eristada kaht eelmainitud modaalsust - mängulist narrimist ja tõsimeelset agressiivsust, pealegi on negatiivsete nimetuste kasutamine harva teadlikult motiveeritud, peamiselt vaid äärmuslikus konfliktsituatsioonis. Ka siin võib ütleja ennast välja vabandada, et kasutas solvavat nimetust vaid naljana ja eksis auditooriumi valikul - või siis heidab solvujatele ette hoopis huumorimeele puudumist, mis omakorda või- 
mendab piire oma ja võõra vahel. Kavatsust on raskem analüüsis kirjeldada ja kontrollida kui vastu võtta. Reaktsiooni teadasaamiseks tuleb uurida, milliseid emotsioone tekitab vaenunimede kasutamine selle objektide seas ja kuidas see mõjutab rahvuste omavahelisi suhteid.

Vaenunimed, nagu ka etnoste stereotüpiseerimine, on juba aastakümneid olnud kriitilise teravapilgulise akadeemilise ja poliitilise vaatluse all. Teadlaste ülesandeks näib poliitilise korrektsuse ajastul olevat teha ettekirjutusi, kuidas vältida kõike, mis võiks õhutada etnilist vaenu. Samas kuuleme vaid harva arvamust, et stereotüüp iseenesest on universaalne kognitiivne tööriist info korrastamiseks ja lihtsustamiseks, mis osutub just tänapäevases etniliselt segunenud maailmas eriti vajalikuks. Ka vaenunimed võivad olla sotsiaalsest kontekstist olenevalt vastupidise, positiivse tähendusega, tekitades (sarnaselt tavasuhtluses kasutatavate negatiivsete hüüdnimedega) pigem siduvat ja rühmatunnet suurendavat efekti. Eriti sage on siin seksuaalse sisuga slängi kasutamine. Kuid see, mis on lubatud omadele, pole kindlasti aktsepteeritav, kui ütlejaks on rühmaväline isik. Peale ambivalentse olemuse (mänguline vaheldub agressiivsega) on vaenunimed heaks indikaatoriks etnilise enesetunnetuse uurimisel ning nende pikemaajaline jälgimine ütleb palju etnilise grupi suhete kohta tema teistega.

\section{Kommentaar}

1 Jaccardi koefitsent näitab ühe muutuja sarnasust teiste võrreldavate muutujatega vahemikus $0-1$.

\section{Kirjandus}

Allen, Irving Lewis 1983. The Language of Ethnic Conflict: Social Organization and Lexical Culture. New York: Columbia University Press.

Allen, Irving Lewis 1990. Unkind Words: Ethnic Labelling From Redskin to Wasp. Greenwood Press: New York.

Billig, Michael 2005. Comic Racism and Violence. Lockyer, Sharon \& Billig, Michael (toim). Beyond a Joke: The Limits of Humour. Palgrave MacMillan: London, lk 25-44.

Cobb, Sara \& Rifkin, Janet 1991. Practice and Paradox: Deconstructing Neutrality in Mediation. Law \& Social Inquiry 16: 1 (Winter), lk 35-62.

Danet, Brenda 1991.Cyberpl@y: Communicating Online. Berg: Oxford, UK.

Giora, Rachel 2002. Optimal innovation and pleasure. Stock, Oliviero \& Strapparava, Carlo \& Nijholt, Anton (toim). The April Fools' Day Workshop on Computational Humour, April 2002, ITC-irst, Trento, lk 11-28. 
Hobden, Karen L. \& Olson, James M. 1994. From Jest to Antipathy: Disparagement Humor as a Source of Dissonance-Motivated Attitude Change. Basic and Applied Social Psychology 15: 3, lk 239-249.

Hughes, Geoffrey 2006. An Encyclopedia of Swearing: The Social History of Oaths, Profanity, Foul Language, and Ethnic Slurs in the English-Speaking World. M. E. Sharpe: New York, London.

Laineste, Liisi (2008, ilmumas). Rassism ja ksenofoobia eesti Internetis. Hanni, Eerik (toim). Rassism ja ksenofoobia Eestis. Justiitsministeerium: Tallinn.

Maio, Gregory R. \& Olson, James M. \& Bush, Jackie E. 1997. Telling Jokes That Disparage Social Groups: Effects on the Joke Teller's Stereotypes. Journal of Applied Social Psychology 27: 22, lk 1986-2000.

Mudde, Cas 2005. Racist Extremism in Central and Eastern Europe. East European Politics and Societies 19: 2, lk 161-184.

Mullen, Brian 2001. Ethnophaulisms for Ethnic Immigrant Groups. Journal of Social Issues 3 , lk 457-475.

Nyíri, Pál 2003. Xenophobia in Hungary: A Regional Comparison. Systemic sources and possible solutions. Center for Policy Studies.Budapest (http://cps.ceu.hu/papers.php 23. jaanuar 2008).

Orwell, George (1946). Politics and the English Language. http://www.george-orwell.org/ Politics_and_the_English_Language (31. jaanuar 2008).

Vaik, Kristin 2006. Milline nimi on "oma”? Hortus Semioticus 1, lk 85-93.

Žagar, Igor 2002. Xenophobia and Slovenian Media: How the Image of the Other is Constructed (And What it Looks Like). Pajnik, Mojca (toim). Xenophobia and Post-Socialism, lk 37-45.

\section{Lisa 1}

Kodeerimispõhimõtted näidetega

\begin{tabular}{|c|c|c|}
\hline Kodeering & Kirjeldus ja näited & $\begin{array}{l}\text { Osatähtsus } \\
\text { materjalis, } \\
\%\end{array}$ \\
\hline \multicolumn{3}{|l|}{ TUGEV } \\
\hline $\begin{array}{l}\text { Diskrimineerimis- } \\
\text { üleskutse }\end{array}$ & $\begin{array}{l}\text { Loosungivormiline üleskutse rahvuse/rassi/religiooni õiguste } \\
\text { piiramisele, nende halvustamisele, stereotüüpide } \\
\text { omaksvõtmisele } \\
\text { /.../ me ei tohi mingil tingimusel lasta sisse venelasi } \\
\text { ükskõik, mis eesmärgil (tööle, perekondade liitmine, } \\
\text { fiktiivabielud) (kluks 22.06. } 2004 \text { 10:05:00 \#5654) }\end{array}$ & 0,5 \\
\hline
\end{tabular}




\begin{tabular}{|c|c|c|}
\hline & $\begin{array}{l}\text { Keegi ei keela meil Eestis venelasi sõimata ja seda me } \\
\text { heameelega teemegi.Ja kui keelabki-sõimame ikkagi (retti } \\
\text { 3. 02. } 2001 \text { 10:55:00 \#1969) }\end{array}$ & \\
\hline $\begin{array}{l}\text { Looritatud } \\
\text { üleskutsed }\end{array}$ & $\begin{array}{l}\text { Tingivas kõneviisis esitatud üleskutsed vägivallale või } \\
\text { diskrimineerimisele: oleks ammu aeg, neile kuluks ära veidi } \\
\text { ópetust, vägisi tahaks midagi ette võtta } \\
\text { kuradi mustlasenässid tuleks lihtsalt peldiku taha tarida } \\
\text { ja (Martin Malm 5. 10. } 2006 \text { 9:56:00 \#11728) } \\
\text { tallinnas peaks ka peksma hakkama neid pakse värdjaid } \\
\text { somme ja filmima :D (Väänik 12.01. } 2007 \text { 7:34:00 } \\
\text { \#14819) }\end{array}$ & 0,7 \\
\hline $\begin{array}{l}\text { Üleskutse } \\
\text { rünnakule }\end{array}$ & $\begin{array}{l}\text { Otsene üleskutse vägivallale, ahju ja mujale ajamise } \\
\text { loosungid } \\
\text { Kutsun üles selle jultunud solvangu eest kättemaksuks } 100 \\
\text { tiblale Eestis kuul pähe! (Inime 3. 02. } 2001 \text { 12:37:00 } \\
\text { \#1976) }\end{array}$ & 0,4 \\
\hline KESKMINE & & \\
\hline $\begin{array}{l}\text { Negatiivsed } \\
\text { stereotüübid }\end{array}$ & $\begin{array}{l}\text { Vene - kultuuritu, kriminaalne, alkohoolik, prostituut, maffia, } \\
\text { peremehetsev } \\
\text { kommunist jagab kultuurist sama palju kui siga } \\
\text { pühapäevasest päevast (galil 4. 02. } 2001 \text { 11:32:00 \#2127) } \\
\text { Silmakirjalikkus, tõe väänamine endale sobivalt, ülbus, } \\
\text { alatus, ahnus jne. - kõik juba korduvalt nähtud (maakas } \\
\text { 20. 03. } 2002 \text { 11:15:00 \#2788) } \\
\text { 98\% kurjategijatest on venelased! (to vene neiu } \\
\text { 19. 08. } 2005 \text { 17:42:00 \#9832) } \\
\text { Juut - sallimatu, manipuleeriv } \\
\text { Tyypiline juudi u su tagapõhjaga kommentaar. Hävitada, } \\
\text { hävitada, hävitada usu nimel...Vôiks nagu natukenegi } \\
\text { sallivust yles näidata (m2s 23. 11. } 200011: 10: 00 \text { \#403) } \\
\text { Stiil on selline, et käsen poon ja lasen ja teie pole üldse } \\
\text { miskit,teie rahva kannatused ei tähenda üldse kellelegi } \\
\text { midagi,tähendavad ainult väljavalitud rahva omad } \\
\text { (eestlanna 24. } 06.2004 \text { \#5832) }\end{array}$ & \\
\hline
\end{tabular}


Negatiivsed stereotüïbid
Eestlane - kade

Parim toit eestlasele on teine eestlane! (adolf

21. 11. 2000 8:28:00 \#64)

Mustanahaline - laisk, himustab eesti naist

Ja mis te põete mingite neegrilaste pärast. Neegrid võiks ise ka midagi teha, mitte ainust humanitaarabist elada (wwwzzz 21. 11. 2000 16:07:00 \#215)

Kes suursaadikuks läheb? Ja kas kandidaat kannibalismis küllalt kogenud on? (Dipolomaat 30. 01. 2001 16:10:00 \#1134 [Eesti avab Gambias saatkonna])

Kristlane - silmakirjalik, pedofiil

Kirikutegelased ongi variserid (nipi 7. 05. 2003 17:52:00 \#4421)

miks kirikumehed, aga selle üle jauravad???

$<b r$ />millega on kirik läbi ajaloo nii väga hiilanud, et üritab eeskujusid pakkuda? kas kiriku tegelaste seas on vähe pedesid, mehe -naise suhte põlgajaid jne? $<b r />e h k$ järjekordne silmakirjalik vusserdis!!! (pauka 5. 10. 2006 12:30:00 \#11870)

Homo - edev, kõlvatu

Rohkem kui pedenduse all kannatavad tü̈̈bid tähelepanu puuduse all (Jyri 15. 08. 2005 13:25:00 \#7012)

Muu:

Mustlased on saatana sigitised maa peal. Terror ja kaos. Mängivad inimese ahnusele ja nende valed on nii suured, et ohvrid jäävad uskuma /.../ (theoty 5. 10. 2006 12:07:00 \#11854)

Eks need soome mehed vihkavad tõesti eestlasi, kuna eestlastel on ilusad naised, aga nemad peavad mingite paksude koletistega elama. yhesõnaga põhjus on leitud (nii see on 11. 01. 2007 21:43:00 \#14531)

/.../ seal kus ilmub usa sõdur hakkab kohe kasvama raev ja vihkamine n.n. demokraatia vastu (ask 6. 10. 2006 18:18:00 \#12482) 


\begin{tabular}{|c|c|c|}
\hline Vaenunimed & $\begin{array}{l}\text { Halvustava sisu või konnotatsiooniga nimed, millega rühma } \\
\text { esindajaid kutsutakse (tavaliselt ühesõnaline, vt ka } \\
\text { vaenunimede ülevaadet lk 17) } \\
\text { mis defineerib Eesti Vabariigi (aga ka Läti) territooriumil } \\
\text { elutsevat vene keelt (või kas või malagashi keelt) } \\
\text { emakeelena tunnustavat isikut, kes on okupatsiooni ajal a. } \\
\text { 1944-1991 Eesti Vabariigi territooriumile asunud/asunute } \\
\text { järglanel ja Eesti Vabariigi riikliku iseseisvuse taastamise } \\
\text { järgselt elamisloa saanud? - Kukusha - kägu, lind keda } \\
\text { iseloomustab võõrastesse pesadesse munemine (Kägu } \\
\text { 22. 06. } 2004 \text { 11:58:00 \#5695) }\end{array}$ & 0,8 \\
\hline \multicolumn{3}{|l|}{ NÕRK } \\
\hline Mingu koju & $\begin{array}{l}\text { Pole neid Eestisse vaja, nende koht on mujal } \\
\text { hirmsad inimesed, oma KODUMAALE! (Minge ometi koju } \\
\text { 24. 06. } 2004 \text { 9:54:00 \#5847) } \\
\text { peded, kas te oma vanemate peale ka mõtlesite, kui } \\
\text { ennast telekas eksponeerisite? ükski vanem ei rõómusta } \\
\text { selliste poegade üle. peitu peaks te pugema. ja nü̈d ruttu } \\
\text { kappi tagasi (fuihh 15. } 08.2005 \text { 15:28:00 \#7077) }\end{array}$ & 1,5 \\
\hline $\begin{array}{l}\text { Meid } \\
\text { diskrimineeritak- } \\
\text { se }\end{array}$ & $\begin{array}{l}\text { Märtristaatuse rõhutamine, väited põliselanike } \\
\text { diskrimineerimise kohta } \\
\text { Eestis diskrimineeritavat venelasi. Kallaveres tuleb } \\
\text { hommikul kell } 6.00 \text { bussipeatusse AS Temptransi buss } \\
\text { liininumbriga } 221 \text { ja nii kui juht bussiukse lahti teeb, } \\
\text { voogab raadiost endine NSV Liidu hümn: “On vabade } \\
\text { riikide murdmatu liidu...” Kas see ei ole minu kui eeestlase } \\
\text { diskrimineerimine? Kui see pole mitte mulle persega näkku } \\
\text { hüppamine sisi mis see on? Keda Eestis siis ikkagi } \\
\text { diskrimineeritakse? (Eestlane 22. 06. } 2004 \text { 8:31:00 \#5636) } \\
\text { mind huvitab pigem, miks kapo ei pööra tähelepanu } \\
\text { siinsele venekeelsele foorumile kus iga päev kutsutakse } \\
\text { üles eestlasi hävitama (to kapo le 3. } 10.2006 \text { 11:17:00 } \\
\text { \#11006) }\end{array}$ & \\
\hline Homoseksuaal & & 0,5 \\
\hline Ameeriklane & & 0,5 \\
\hline Eestlane & & 1,4 \\
\hline
\end{tabular}




\begin{tabular}{|l|l|l|}
\hline Eurooplane & & 0,3 \\
\hline Juut & & 0,1 \\
\hline Lähis-ida & & 0,1 \\
\hline Lätlane & & 0,4 \\
\hline Venelane & & 0,0 \\
\hline Sakslane & & 0,0 \\
\hline Ukraina & & 9,8 \\
\hline Türgi, kurd & & 0,1 \\
\hline Soomlane & & 0,0 \\
\hline Mustlane & & 0,1 \\
\hline Vene vähemused & & 0,4 \\
\hline Inglise & nelipühilased, adventistid, jehoovatunnistajad jne & 0,1 \\
\hline Kollane rass & & 0,3 \\
\hline Must rass & & 0,0 \\
\hline Moslem & & 0,0 \\
\hline Õigeusklik & & 0,1 \\
\hline Uued usud & & 0,3 \\
\hline Kristlus & & 0,0 \\
\hline Euroliit & & \\
\hline
\end{tabular}




\title{
Summary
}

\section{Dysphemisms on the Estonian Internet}

\author{
Liisi Laineste
}

Key words: aggressive nicknames, aggression, ethnic slur, dysphemisms, web lore, ethnic humour

Ethnic, religious or other group-based dysphemisms are the most obvious manifestations of prejudice, ethnocentrism, sometimes even indicating actual feelings of xenophobia. But they also mirror the present and past on interethnic relationships, as slurs and dysphemisms are part of a nation's or a group's reactions to culture contacts, for example to the ethnic diversification of society. Nicknames are affected by quite objective factors like the amount and density of population, migration, etc., becoming more aggressive in the context of insecurity, fast and unanticipated changes, or perceived/actual threat on the welfare of the group. The present study focuses on the use of aggressive nicknames in the Estonian web from the sociological and folkloristic perspective. The material covers the years 2000-2007 and features news comments posted on the Estonian online news portal www.delfi.ee from a selection of one-week periods from each year. The study describes the main objects of online flaming and the social background of target choice.

The results show that online commenters play with the concepts of normal and abnormal, right and wrong, good and bad, while naming the "other". They display their (sometimes radical) nationalism through juxtaposing themselves to "abnormal groups". Temporal dynamics of ethnic and other hate speech in news comments show that the highest relative amount of slurs were used in 2003, regardless of the rise in national consciousness following the public disturbances in Estonia in April 2007. This trend is supported by the rise in other categories and by a sharp and direct confrontation to the "other" in Internet comments (but also the news themselves) during 2003. In the last years, commenters appear to use much less aggressive and straightforwardly offensive language to characterise groups other than their own. The trends show higher sensitivity and sense of responsibility, and the use of argument for the need of political correctness, possible censorship or even fear of punishment. The biggest number of instances of offensive slang are directed against Russians, while homosexualism and religion are also targets of dysphemisms. At the same time, ethnic slurs against Russians are proportionally much lower than those used against Gypsies, the Black or gays. Thus, as the number of comments in the case of a news story about Gypsys, for example, is much smaller than in the case of (very often provocative and emotional) news featuring Russians, the relative amount is somewhat distracting. The use and intensity of flaming also depends on many contextual cues: the news story and its construction, its main subjects, the identity or attitudes of the commenting persons, the social context of the news, etc. 
Dysphemisms as indicators of a nation's self-identification and feelings of ethnic or other superiority are here described as a general phenomena in the Estonian Internet. A more detailed study of the social psychological aspects is needed on how the public, media, politicians, or targeted groups perceive flaming. In addition, a historical overview of Estonian ethnic slurs, religious and other nicknames and their etymology would be in order. 